\title{
Sintomas da IntoxicaÇÃo Inicial de Eucalyptus Proporcionados por Subdoses de Glyphosate Aplicadas no Caule ou nas Folhas ${ }^{1}$
}

\author{
Initial Symptoms of Eucalyptus Intoxication by Glyphosate Rates Applied on the Stem or Leaves
}

\author{
SALGADO, T.P. ${ }^{2}$, ALVES, P.L.C.A. ${ }^{3}$, KUVA, M.A. ${ }^{2}$, TAKAHASHI, E.N. ${ }^{4}$, DIAS, T.C.S. ${ }^{6}$ e \\ LEMES, L.N. ${ }^{5}$
}

\begin{abstract}
RESUMO - Com o objetivo de avaliar os sintomas de intoxicação causados pela aplicação de glyphosate, foi montado um estudo composto por quatro ensaios com aplicações de glyphosate (360 g e.a. $\mathrm{L}^{-1}$ ) em eucalipto. Em todos os ensaios, mudas foram transplantadas em vasos de 5,0 L. Nos ensaios 1 e 2, foram aplicados volumes crescentes de solução de glyphosate no caule do eucalipto. No ensaio 1 , a solução de $3 \%(\mathrm{v} / \mathrm{v})$ foi aplicada nos volumes de $0,1,5,10$, 20, 40, 80 e $160 \mu \mathrm{L}$ de calda por planta e, no segundo, a solução de glyphosate a $2 \%$ (v/v) foi aplicada nos volumes de $0,1,5,15,30,60,90,120$ e $150 \mu \mathrm{L}$ de calda por planta. Nos ensaios 3 e 4, foram feitas aplicações de glyphosate sobre as plantas de eucalipto. No ensaio 3, as doses foram de $0,7,2.10^{-7}, 7,2.10^{-6}, 7,2.10^{-5}, 7,2.10^{-4}, 7,2.10^{-3}, 7,2.10^{-2}, 7,2.10^{-1}, 7,2,72,360 \mathrm{e}$ 720 g e.a. de glyphosate ha-1 e, no ensaio 4, de 0, 9, 18, 36, 72, 144, 288, 432, 576, 720, 1.080, 1.440 e $2.160 \mathrm{~g}$ e.a. de glyphosate $\mathrm{ha}^{-1}$. Nos quatro ensaios foi utilizado o delineamento DIC, com três repetições. Nas plantas, foram avaliadas a altura, a área foliar e a matéria seca de caule e folhas. Os resultados obtidos foram submetidos a análises de regressão. Quando aplicadas no caule, doses de 40,78 e 51,41 $\mu \mathrm{L}$ de calda por planta de glyphosate a 3 e $2 \%$ (v/v), respectivamente, nos ensaios 1 e 2, foram suficientes para redução média de 50\% das características estudadas. Nas aplicações sobre as folhas, houve maior sensibilidade das plantas mais desenvolvidas. Para redução média de 50\% nas variáveis analisadas, foram necessárias doses de 277,4 e 143,3 g e.a. de glyphosate ha ${ }^{-1}$ nos ensaios 3 e 4, respectivamente.
\end{abstract}

Palavras-chave: crescimento, deriva, fitointoxicação, floresta, herbicidas.

\begin{abstract}
This work was carried out to evaluate intoxication symptoms caused by glyphosate application. It was constituted by four assays with glyphosate applications (360 g a.e. $L^{-1}$ ) on eucalyptus. In all assays, seedlings were transplanted into 5.OL plastic pots. In assays 1 and 2, increasing herbicide volumes were applied on the stem. In the first one, a glyphosate solution of 3\% $(v / v)$ was applied at the volumes $0,1,5,10,20,40,80$ and $160 \mu \mathrm{L}$ solution per plant, and in the second, glyphosate solution of $2 \%(v / v)$ was applied at volumes $0,1,5,15,30,60,90,120$ and $150 \mu \mathrm{L}$ solution per plant. In assays 3 and 4, glyphosate was sprayed on the plants. The rates in the third assay were: $0,7.210^{-7}, 7.210^{-6}, 7.210^{-5}, 7.210^{-4}, 7.210^{-3}, 7.210^{-2}, 7.210^{-1}, 7.2,72,360$ and $720 \mathrm{~g}$ a.e. of glyphosate $\mathrm{ha}^{1}$, and in the fourth assay, the rates were: 0, 9, 18, 36, 72, 144, 288, 432, 576, 720, 1.080, 1.440 and $2.160 \mathrm{~g}$ a.e. of glyphosate ha ${ }^{-1}$. All assays were arranged in a randomized design, with three replications. Height, leaf area, and dry mass of the leaves and stem were evaluated in the plants and the results were submitted to regression analysis. When applied on the stem, doses of 40.78 and $51.41 \mu \mathrm{L}$ per plant of glyphosate solution, 3 and $2 \%(v / v)$, respectively, were sufficient to reduce eucalyptus development in $50 \%$. When applied on the plants, more developed plants showed greater sensitivity.Rates of 277.4 and $143.3 \mathrm{~g}$ a.e. ha-1 reduced eucalyptus growth in 50\%, in assays 3 and 4, respectively.
\end{abstract}

Keywords: growth, drift, plant toxicity, forest, herbicides.

Recebido para publicação em 28.7.2010 e aprovado em 25.2.2011.

2 Herbae - Consultoria e Projetos Agrícolas Ltda, <tpsalgado@herbae.com.br >; <mkuva@herbae.com.br >; ${ }^{3}$ Dep. de Biologia, Universidade Estadual Paulista, <plalves@fcav.unesp.br>; ${ }^{4}$ Fibria Celulose e Papel, <ernesto.takahashi@fibria.com.br>; ${ }^{5} \mathrm{CAROL}$ SODRU S.A, <tcsdias@yahoo.com.br>; ${ }^{6}$ Syngenta Proteção de Cultivos Ltda., <lucio.lemes@syngenta.com>

Planta Daninha, Viçosa-MG, v. 29, n. 4, p. 913-922, 2011 


\section{INTRODUÇÃO}

Após uma desacelerada no crescimento do setor florestal por causa da crise mundial, o ano de 2010 foi marcado pela retomada de consumo e investimentos (Abraf, 2009). Para garantir a expressão do teto produtivo dos materiais de eucalipto, suprir a demanda de consumo e consolidar o avanço do setor, um bom manejo das plantas daninhas deverá ser realizado.

Trabalhos de pesquisa demonstraram os efeitos prejudiciais da interferência das plantas daninhas, principalmente no início do desenvolvimento do eucalipto (Brendolan et al., 2000; Tarouco et al., 2009), cujo controle químico é o mais eficaz e o mais recomendado ao setor florestal para evitar ou minimizar os efeitos da interferência (Toledo et al., 2003). Esse controle pode ser feito com herbicidas aplicados em pré ou pós-emergência e seletivos ou não à cultura.

O glyphosate é um herbicida não seletivo ao eucalipto, porém com baixo risco ambiental e toxicológico, elevado espectro de ação e custo competitivo, sendo, por isso, o mais usado pelo setor. Herbicidas à base de glyphosate têm sido aplicados na dessecação pré-plantio, no controle das plantas daninhas na linha e entrelinha e também para eliminação do eucalipto. $\mathrm{O}$ uso generalizado do produto para o controle químico de plantas daninhas em diversas etapas do processo produtivo aumenta o risco da deriva acidental, pois as pulverizações podem ser feitas sob as mais diferentes condições climáticas. Normalmente podem ser feitas de duas a cinco pulverizações de glyphosate por ano na cultura, sem considerar o risco de intoxicação por aplicações em áreas adjacentes (Takahashi et al., 2009).

O emprego de herbicidas deve cercar-se de uma série de cuidados a fim de evitar os problemas relativos à deriva, que pode atingir a própria cultura, cultivos vizinhos e/ou alvos indesejáveis, até intoxicações sofridas pelo homem e animais, além de consequências muitas vezes irreversiveis ao ambiente.

Sob condições climáticas ideais para aplicação, a deposição de produtos devido à deriva gira em torno de 5 a 9\% da dose aplicada com equipamentos terrestres (Bode, 1984).
Cunha (2008), estudando a distância horizontal percorrida por gotas de tamanho conhecido, submetidas a três diferentes alturas $(0,3,0,5$ e $0,8 \mathrm{~m}$ ) de lançamento e cinco velocidades do vento $\left(1,0,2,0,3,0,4,0\right.$ e $\left.5,0 \mathrm{~m} \mathrm{~s}^{-1}\right)$, concluiu que a deriva pode chegar a $40 \mathrm{~m}$ quando as gotas forem menores que $100 \mu \mathrm{m}$. Em casos especiais, como a pulverização aérea de herbicidas não seletivos, os cuidados devem ser redobrados para prevenir a deriva. Segundo os autores, em pulverizações com ventos de $2 \mathrm{~m} \mathrm{~s}^{-1}$, a deriva de glyphosate pode atingir até $160 \mathrm{~m}$, e a de sulfosate, até $200 \mathrm{~m}$ do local considerado alvo.

Diante do exposto, o risco da deriva acidental no campo é muito evidente. Dessa maneira, estudos devem ser realizados para confirmar e quantificar os danos nas plantas. Na cultura do eucalipto, os efeitos de subdoses de glyphosate no caule ou sobre as plantas devem ser melhor compreendidos. O objetivo deste trabalho foi avaliar os sintomas de intoxicação inicial em plantas de Eucalyptus que receberam subdoses de glyphosate no caule ou nas folhas.

\section{MATERIAL E MÉTODOS}

O presente estudo foi composto por quatro ensaios, conduzidos em área anexa ao Laboratório de Biologia e Manejo de Plantas Daninhas da FCAV/UNESP, campus de Jaboticabal/SP. Nesses ensaios, foram utilizadas duas formas de aplicação de glyphosate (Roundup Original, 360 g e.a. $\mathrm{L}^{-1}$ ) em mudas recém-estabelecidas de eucalipto.

$\mathrm{Na}$ primeira, foram aplicadas gotas da solução do herbicida no caule (ensaios 1 e 2), e na segunda, foi pulverizado o herbicida sobre a parte aérea das plantas (ensaios 3 e 4).

Em todos os ensaios, mudas pré-selecionadas de um clone de híbrido de Eucalyptus grandis $\mathrm{x} E$. urophylla foram transplantadas em vasos plásticos com capacidade de 5,0 L, preenchidos com solo (Neossolo Quartzarênico), que foi coletado na camada arável de área de produção comercial de eucalipto da VCP (Fibria S.A), em São Simão, SP. Para a nutrição e crescimento das mudas, além da irrigação diária, a cada dois dias foi adicionado aos vasos $0,5 \mathrm{~L}$ de solução nutritiva completa. 
Nos ensaios 1 e 2, foi feita aplicação de volumes crescentes do herbicida glyphosate no caule do eucalipto. Baseando-se em resultados de ensaios preliminares, no primeiro ensaio, uma solução de glyphosate (360 g e.a. $\left.\mathrm{L}^{-1}\right)$ na concentração de $3 \%(\mathrm{v} / \mathrm{v})$ foi aplicada nos volumes de $0,1,5,10,20,40,80$ e $160 \mu \mathrm{L}$ de solução por planta, que representam 0 ; $1,08 \cdot 10^{-5} ; 5,40.10^{-5} ; 1,08 \cdot 10^{-4} ; 2,16 \cdot 10^{-4}$; $4,32 \cdot 10^{-4} ; 8,64 \cdot 10^{-4} ;$ e $1,73 \cdot 10^{-3}$ g e.a. por planta, respectivamente. No segundo ensaio, as aplicações da solução de glyphosate a $2 \%(\mathrm{v} / \mathrm{v})$ foram feitas nos volumes de $0,1,5,15,30$, $60,90,120$ e $150 \mu \mathrm{L}$ de solução por planta, que representam $0 ; 7,2.10^{-6} ; 3,6 \cdot 10^{-5} ; 1,08 \cdot 10^{-4}$; $2,16 \cdot 10^{-4} ; 4,32 \cdot 10^{-4} ; 6,48 \cdot 10^{-4} ; 8,64 \cdot 10^{-4}$; e $1,08 \cdot 10^{-3}$ g e.a. por planta, respectivamente. Nos dois ensaios, o glyphosate foi depositado no caule principal das plantas de eucalipto, a cerca de 0,10 m do solo. Essa aplicação foi feita com o uso de micropipetas automáticas, tomando-se cuidado para não haver escorrimento da solução pelo caule.

Nos ensaios 3 e 4, foram feitas aplicações de doses crescentes de glyphosate sobre as plantas de eucalipto. Para isso, foi utilizado um pulverizador costal à pressão constante $\left(\mathrm{CO}_{2}\right)$, munido de barra com quatro pontas XR 11002 , espaçadas de $0,5 \mathrm{~m}$, regulado com 2,0 bar de pressão para um gasto de $200 \mathrm{~L} \mathrm{ha}^{-1}$ de volume de calda. Na ocasião das aplicações, a barra de pulverização estava a $0,5 \mathrm{~m}$ do alvo. No ensaio 3, as doses de glyphosate foram de: 0 , $7,2 \times 10^{-7}, 7,2 \times 10^{-6}, 7,2 \times 10^{-5}, 7,2 \times 10^{4}, 7,2 \times 10^{-3}$, $7,2 \times 10^{-2}, 7,2 \times 10^{-1}, 7,2,72,360$ e 720 g e.a. de glyphosate ha ${ }^{-1}$ e, no ensaio 4 , de: $0,9,18,36$, $72,144,288,432,576,720,1.080,1.440$ e 2.160 g e.a. de glyphosate ha ${ }^{-1}$. No momento das aplicações, a temperatura do ar foi de 26,0 e $21,3{ }^{\circ} \mathrm{C}$ e a umidade relativa do ar, de 49 e $63 \%$, respectivamente, nos ensaios 3 e 4 . A descrição das plantas no dia de aplicação de cada ensaio encontra-se na Tabela 1 .
Nos quatro ensaios foi utilizado o delineamento inteiramente casualizado, com os tratamentos em três repetições, sendo considerado como parcela experimental cada vaso contendo uma planta. Nas plantas, foram avaliadas a altura, área foliar (LiCor, mod. LI 300A), matéria seca de caule e folhas, aos 23 dias após a aplicação (DAA) no ensaio 1, aos 30 DAA nos ensaios 2 e 3 e aos 21 DAA no ensaio 4. A matéria seca foi obtida após a secagem dos materiais em estufa com circulação forçada de ar a $70{ }^{\circ} \mathrm{C}$, até obter massa constante. Os resultados obtidos nos quatro ensaio foram submetidos a análises de regressão, utilizando o programa MicroCal Origin v. 6.0.

\section{RESULTADOS E DISCUSSÃO}

No momento da aplicação da solução de glyphosate a $3 \%(\mathrm{v} / \mathrm{v})$ no caule - ensaio 1 constatou-se que, em média, as mudas de eucalipto estavam com $0,52 \mathrm{~m}$ de altura e que durante o período experimental (23 dias) houve acréscimo de 33,8\% na altura das plantas na testemunha. Foram necessários $31,5 \mu \mathrm{L}$ de glyphosate para causar inibição de $50 \%$ na altura das plantas (Figura 1A). Essa inibição foi principalmente devido ao encurvamento apical das plantas, secamento e morte. Esses dados corroboram os de Tuffi Santos et al. (2006), que, em ensaio de simulação de deriva de glyphosate, verificaram que aplicações sobre o terço inferior do eucalipto provocaram a morte dos ápices das plantas em Eucalyptus grandis, E. urophylla, E. saligna e E. pellita aos 15 DAA.

Quanto à área foliar, verificou-se que as mudas estavam inicialmente com $7,9 \mathrm{dm}^{2}$ e que após a aplicação do herbicida houve acréscimo de $367,9 \%$ nessa variável na testemunha. A aplicação do herbicida em baixos volumes da solução $(3 \% \mathrm{v} / \mathrm{v})$ já foi suficiente

Tabela 1 - Média de altura, área foliar, matéria seca de caule e folhas do eucalipto no momento das aplicações

\begin{tabular}{|c|c|c|c|c|c|}
\hline \multirow{2}{*}{ Ensaio } & \multirow{2}{*}{ Data da aplicação } & \multirow{2}{*}{$\begin{array}{c}\text { Altura } \\
(\mathrm{m})\end{array}$} & \multirow{2}{*}{$\begin{array}{c}\text { Área foliar } \\
\left(\mathrm{dm}^{2}\right)\end{array}$} & \multicolumn{2}{|c|}{ Matéria seca $(\mathrm{g})$} \\
\cline { 4 - 6 } & & 0,52 & 793,04 & 9,60 & Caule \\
\hline 1 & $28 / 08 / 2002$ & 0,63 & $1.861,60$ & 7,92 & 13,45 \\
\hline 2 & $04 / 02 / 2003$ & 0,40 & $\mathbf{2 1 9 , 6 8}$ & $\mathbf{1 , 2 2}$ & 2,07 \\
\hline 3 & $17 / 06 / 2002$ & 0,69 & $\mathbf{1 . 2 8 5 , 9 0}$ & $\mathbf{5 , 3 0}$ & $\mathbf{7 , 8 0}$ \\
\hline 4 & $24 / 07 / 2002$ & &
\end{tabular}



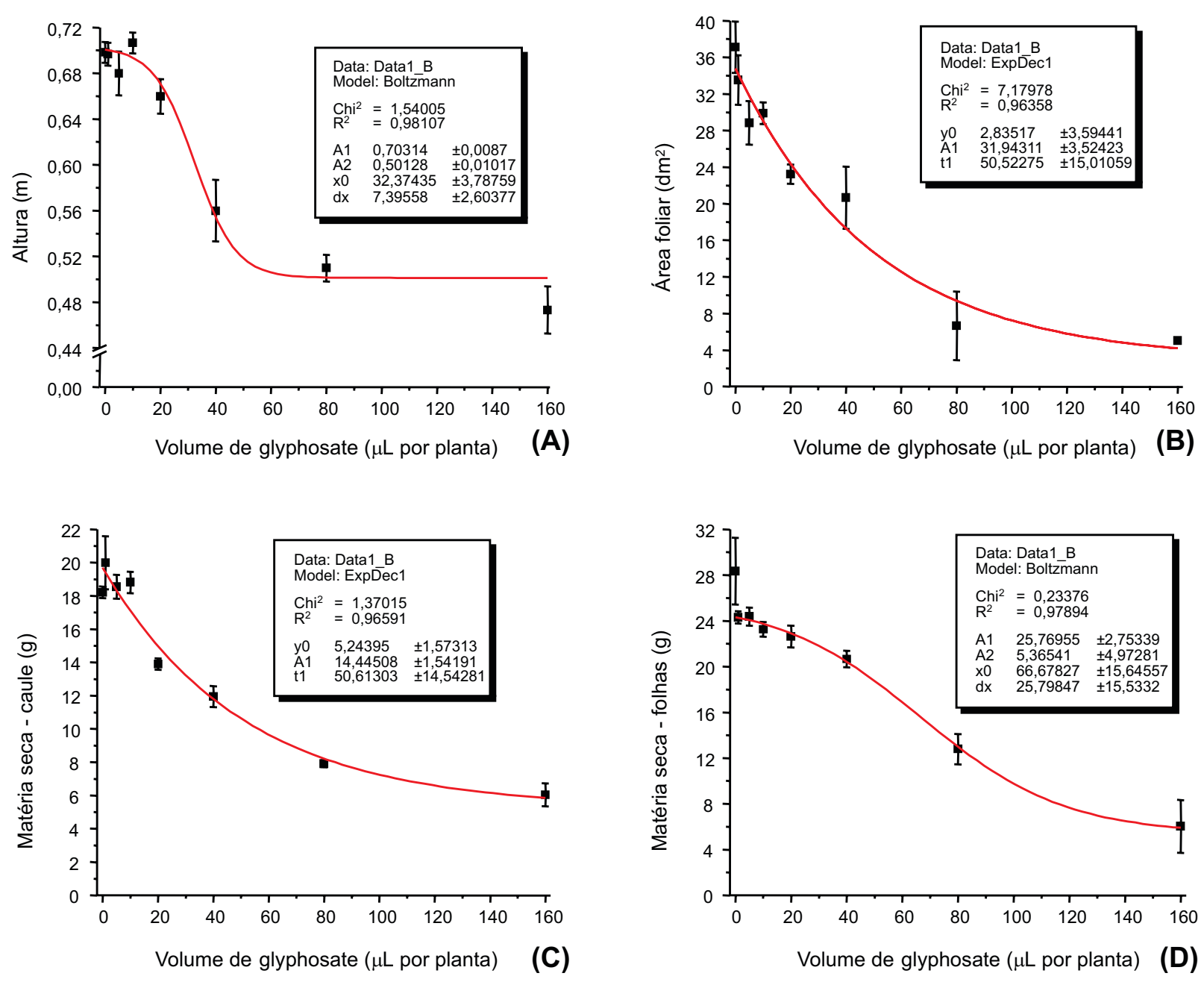

Figura 1 - Altura (A), área foliar (B) e matéria seca de caule (C) e folhas (D) de eucalipto submetido a aplicações de glyphosate no caule (ensaio 1).

para redução exponencial da área foliar das plantas de eucalipto. Essa redução foi menos acentuada à medida que se aumentaram as doses de glyphosate (Figura 1B). Esse comportamento foi muito evidente, provavelmente pelo elevado ganho percentual em área foliar do eucalipto durante o período experimental.

Para a matéria seca (MS) de caule e folhas, os ganhos percentuais durante o ensaio foram de 97,0 e $110,7 \%$, respectivamente. A matéria seca de caule (Figura 1C) também foi reduzida exponencialmente. Foram necessários $31,7 \mu \mathrm{L}$ de glyphosate para inibir em $50 \%$ os acúmulos de matéria seca de caule e $67,2 \mu \mathrm{L}$ de glyphosate a $3 \%(\mathrm{v} / \mathrm{v})$ para a matéria seca das folhas (Figura 1D), quando comparados à testemunha sem aplicação de glyphosate.
As doses recomendadas de glyphosate para o controle de plantas daninhas na cultura de eucalipto variam de 360 a 1.800 g e.a. ha ${ }^{-1}$. Supondo que $1,0 \%$ da menor dose recomendada de glyphosate seja oriunda de deriva e que ela $\left(3,6\right.$ g e.a. ha $\left.{ }^{-1}\right)$ atinja proporcionalmente o caule de cada planta, de uma população de 1.333,3 plantas de eucalipto ha ${ }^{-1}$, cada uma receberia o equivalente a $2,7.10^{-3}$ g e.a. Comparando essa simulação com os resultados obtidos neste ensaio, foram necessários $4,4 \cdot 10^{-3}$ g e.a. por planta ou $40,78 \mu \mathrm{L}$ por planta para a redução de $50 \%$ do crescimento das plantas, considerando a média das quatro características analisadas (altura, área foliar, matéria seca de caule e folhas). Cabe ressaltar que, segundo os fabricantes de glyphosate, a absorção do herbicida pode ser realizada 
por qualquer parte verde de plantas, incluindo folhas, caules e ramos. Portanto, aplicações que atinjam caules verdes de eucalipto devem ser evitadas.

Em relação ao ensaio 2, no momento da aplicação as plantas de eucalipto estavam com 0,63 m de altura, 18,61 $\mathrm{dm}^{2}$ de área foliar, $7,72 \mathrm{~g}$ de matéria seca do caule e $12,12 \mathrm{~g}$ de folhas. Do início até o final do experimento (30 dias), houve acréscimo de 45,3\% na altura do eucalipto. A aplicação de $25,0 \mu \mathrm{L}$ da solução de glyphosate a $2 \%(\mathrm{v} / \mathrm{v})$ no caule proporcionou decréscimo de $50 \%$ na altura das plantas (Figura 2A), e foi necessária uma dose três vezes maior $(75,4 \mu \mathrm{L}$ de glyphosate) para reduzir a área foliar nos mesmos patamares. No final do experimento, cada $1,0 \mu \mathrm{L}$ da solução a
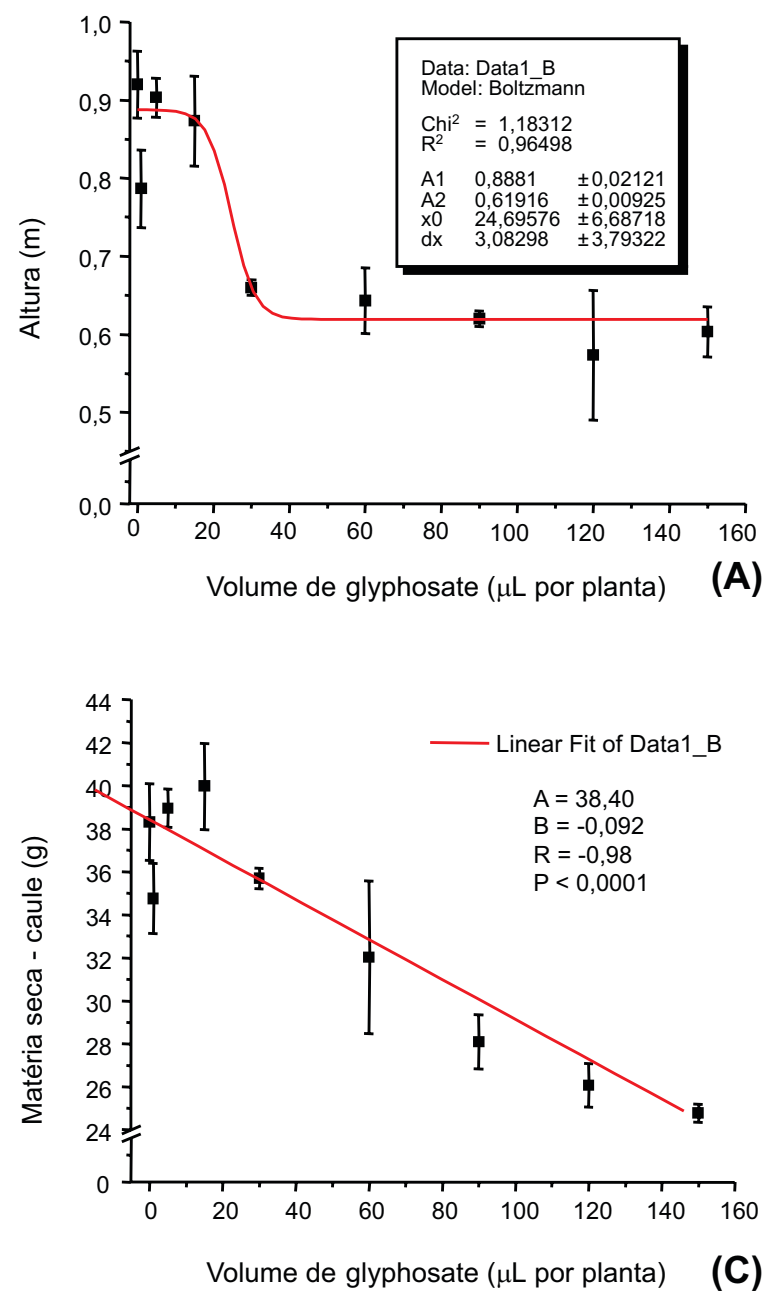

$2 \%(\mathrm{v} / \mathrm{v})$ aplicada no caule do eucalipto proporcionou redução de $0,3 \mathrm{dm}^{2}$ de área foliar.

Neste ensaio também houve comportamento diferencial para as características avaliadas. Para a altura e matéria seca de folhas (Figura 2A, e D), a redução seguiu um modelo sigmoidal, enquanto para área foliar e matéria seca de caule (Figura 2B, e C) a redução foi linear. Esses resultados indicam maior sensibilidade da área foliar e matéria seca do caule às menores doses de glyphosate testadas, quando comparados aos de altura e matéria seca de folhas, ou seja, a aplicação de baixas doses do herbicida no caule é suficiente para inibição exponencial (ensaio 1) ou linear (ensaio 2) na área foliar e matéria seca do caule.
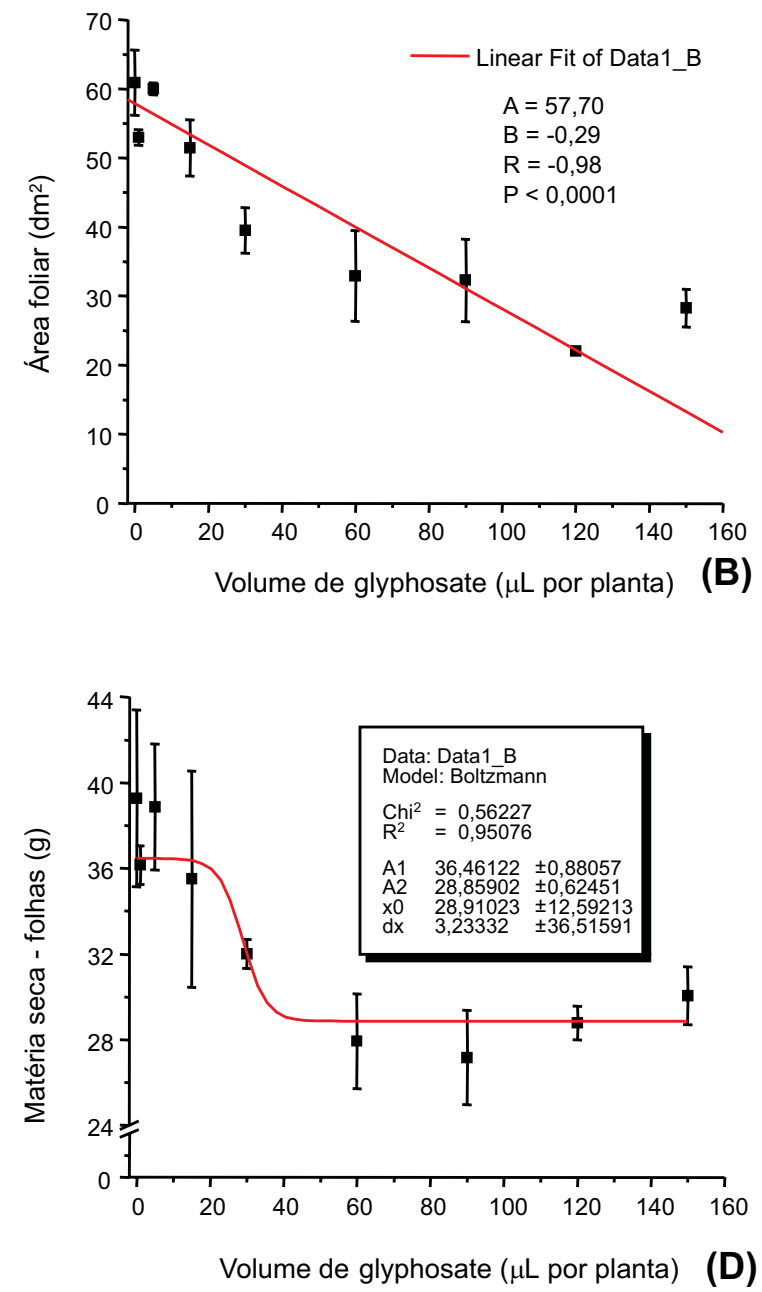

Figura 2 - Altura (A), área foliar (B) e matéria seca de caule (C) e folhas (D) de eucalipto submetido a aplicações de glyphosate no caule (ensaio 2). 
Durante o período experimental, houve acréscimo de 383,8 e $224,1 \%$ na matéria seca de caule e folhas, respectivamente. Foram necessários $76,1 \mu \mathrm{L}$ de glyphosate para a redução de $50 \%$ na matéria seca do caule e $29,1 \mu \mathrm{L}$ para a redução da matéria seca das folhas.

O comportamento diferencial entre matéria seca de folhas e área foliar se deve, provavelmente, à modificação de folhas normais para folhas coriáceas em função da aplicação de glyphosate nas plantas, provocando essa relação desproporcional entre área foliar e matéria seca de folhas. Esse efeito foi observado visualmente nas plantas de ambos os ensaios. Sintomas de folhas coriáceas em plantas de eucalipto submetidas à deriva de glyphosate também foram relatados por Tuffi Santos et al. (2005).

Foram necessários em média $3,7 \cdot 10^{-4} \mathrm{~g}$ e.a. de glyphosate ou $51,41 \mu \mathrm{L}$ de solução de glyphosate a $2 \%(\mathrm{v} / \mathrm{v})$ por planta para redução média de $50 \%$ das características: altura, área foliar, matéria seca de caule e folhas.

Durante a condução dos ensaios houve elevado ganho percentual em altura, área foliar e matéria seca de caule e folhas no eucalipto, indicando alta atividade metabólica das plantas, mesmo quando desenvolvidas em vasos plásticos. Essa intensa atividade metabólica favorece a translocação do produto na planta, pois o herbicida é absorvido pelo tecido vivo e translocado, via floema, em direção às partes das plantas que utilizam esses açúcares, estabelecendo-se uma relação de fonte e dreno (Caseley \& Coupland, 1985). O glyphosate nos vegetais inibe a ação da enzima enolpiruvil shikimato-3-fosfato sintase (EPSP), impedindo a sintese de aminoácidos aromáticos, que são precursores de outras substâncias, como alcaloides, flavonoides e lignina (Amarante Júnior et al., 2002). As plantas tratadas com glyphosate morrem lentamente, em poucos dias ou semanas, e, devido ao seu transporte por todo o sistema, nenhuma parte da planta sobrevive.

No ensaio 3 , constatou-se que a altura média das plantas de eucalipto no momento da aplicação era de 0,40 m e que após 30 dias de condução do ensaio houve acréscimo de $45,7 \%$ na altura (Figura 3A). A dose de
220,5 g e.a. ha ${ }^{-1}$ de glyphosate sobre o eucalipto proporcionou redução de $50 \%$ na altura das plantas, porém a redução iniciou-se em doses a partir de 87,03 g e.a. ha ${ }^{-1}$. Comportamento semelhante foi verificado para área foliar e matéria seca de folhas (Figura 3B e D), cuja redução dos valores também se iniciou por volta dos 90,0 g e.a. ha ${ }^{-1}$. Para a matéria seca do caule, a inibição foi verificada em doses menores, a partir de 30 g e.a. ha ${ }^{-1}$. Tuffi Santos et al. (2005) relataram sintomas foliares em plantas de Eucalyptus urograndis pulverizadas com 172,8 e $345,6 \mathrm{~g} \mathrm{ha}^{-1}$ de glyphosate.

No momento da aplicação, as mudas estavam com $2,2 \mathrm{dm}^{2}$ de área foliar e apresentavam 1,22 e 2,07 g de matéria seca de caule e folhas, respectivamente. Doses de 720 g e.a. ha ${ }^{-1}$ foram suficientes para paralisar o crescimento ou até causar a morte das plantas. Para redução de $50 \%$ de acúmulo de área foliar, matéria seca de caule e folhas, foram necessárias doses de 360,3, 244,4 e 284,3 g e.a. ha ${ }^{-1}$, respectivamente.

Em trabalhos realizados na cultura do algodão, Yamashita \& Guimarães (2005) observaram leves sintomas de intoxicação nas folhas do algodoeiro quando tratadas com $270 \mathrm{~g} \mathrm{ha}^{-1}$ de glyphosate. Miller et al. (2004) relataram a intoxicação somente em doses superiores a $140 \mathrm{~g} \mathrm{ha}^{-1} \mathrm{em}$ algodão não transgênico. Essa resposta do algodoeiro em relação ao glyphosate difere de outras culturas, como milho e sorgo, para as quais os danos são altos em doses inferiores a $172 \mathrm{~g} \mathrm{ha}^{-1}$ (Magalhães et al., 2001).

No ensaio 4, constatou-se que no momento da aplicação a altura das mudas de eucalipto era de $0,69 \mathrm{~m}$. Aos 21 DAA observou-se que doses a partir de 98,3 g e.a. de glyphosate ha ${ }^{-1}$ foram suficientes para causar decréscimo de $50 \%$ na altura das mudas.

Comparando a redução percentual de altura nos ensaios 3 e 4, nota-se que no ensaio 4 as plantas estavam muito mais desenvolvidas no momento da aplicação, porém foram necessárias doses menores do herbicida glyphosate para causar o mesmo efeito negativo em seu crescimento. Esses resultados podem ser justificados pelo efeito fonte/dreno, 

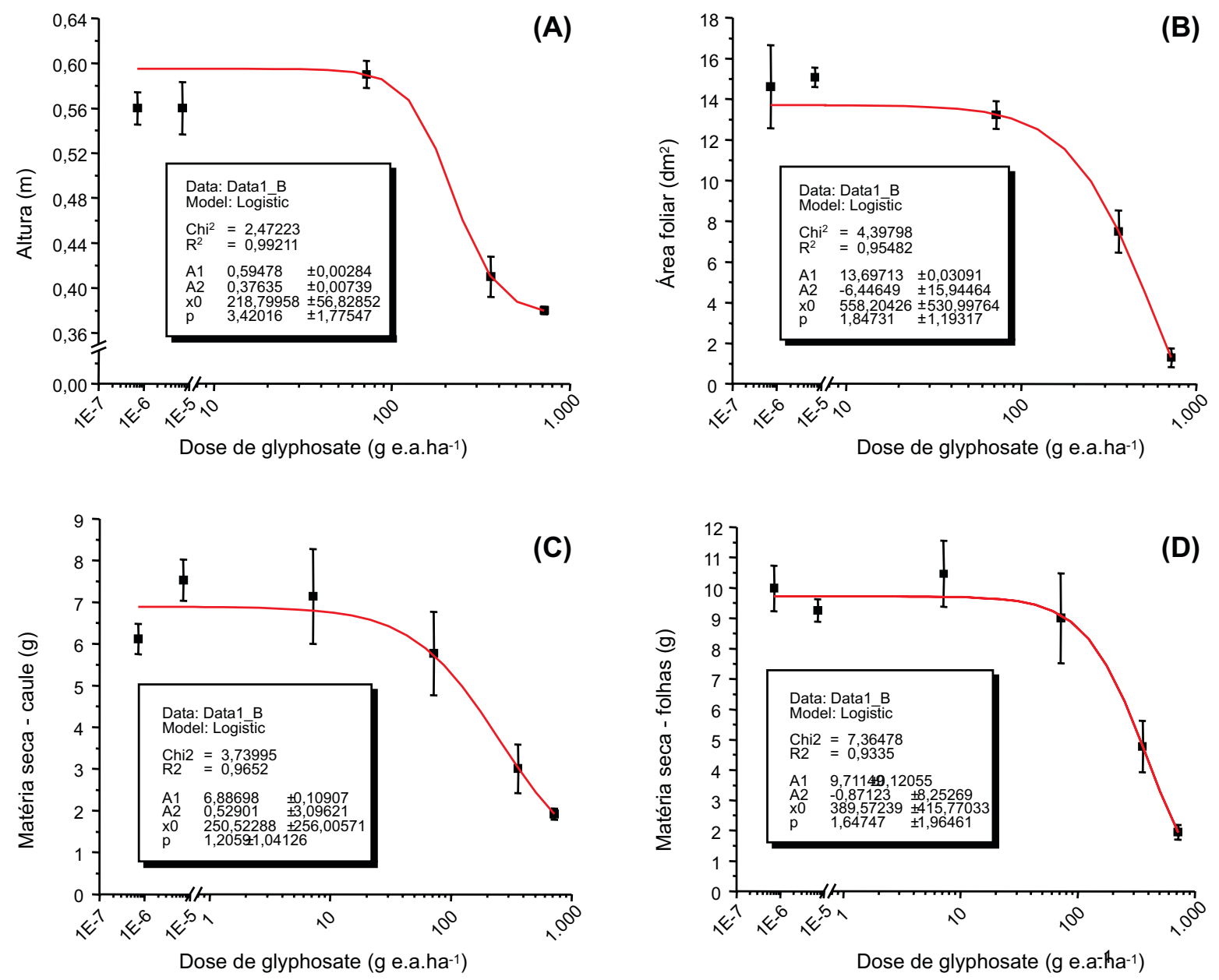

Figura 3 - Altura (A), área foliar (B) e matéria seca de caule (C) e folhas (D) de eucalipto submetido a aplicações de glyphosate (ensaio 3).

pois em mudas recém-transplantadas o dreno de translocação do herbicida provavelmente é maior para as raizes, causando algum efeito de exsudação radicular do produto. Trabalhando com absorção e translocação de glyphosate em dois clones de eucalipto, Machado (2009) observou que, duas horas após a aplicação, 51,7 e 57,4\% de todo o herbicida presente nas plantas foram detectados no sistema radicular dos clones 2277 e 531, respectivamente. A velocidade de translocação do glyphosate para as raízes está associada ao transporte de açúcares no floema, que é rápido e, em geral, pode variar de 0,3 a 1,5 $\mathrm{m} \mathrm{h}^{-1}$ (Taiz $\&$ Zeiger, 2004).

Em relação à área foliar, houve acréscimo de $223,1 \%$ na testemunha durante os 20 dias de condução do ensaio. No momento da aplicação, as mudas estavam com 12,8 dm². Baixas doses de glyphosate já foram suficientes para iniciar a redução exponencial da área foliar. Dose de 121,33 g e.a. ha ${ }^{-1}$ foi suficiente para reduzir a área foliar em $50 \%$, ou seja, evitar o acúmulo de área foliar em 50\%. Doses de 158,6 e 195,1 g e.a. ha-1 foram suficientes para reduzir pela metade o acúmulo de matéria seca de caule e folhas, respectivamente, que estavam em média com 5,3 e 7,8 g de matéria seca por planta no dia da aplicação. Magalhães et al. (2001), trabalhando com simulação de deriva do glyphosate na cultura de sorgo, afirmaram que os prejuízos são diretamente proporcionais ao aumento das doses do herbicida. Esses autores relataram que, a partir de 115,29 g e.a. ha-1 de glyphosate, as plantas tratadas apresentaram necroses na parte aérea e comprometimento na produtividade, chegando a 53\% de intoxicação com 172,8 g e.a. ha ${ }^{-1}$ do herbicida. 
Ao comparar os ensaios 3 e 4, nota-se que as plantas de eucalipto estavam mais sensiveis às mesmas doses de glyphosate no quarto ensaio. Para a redução média de 50\% das quatro variáveis analisadas (altura, área foliar e matéria seca de caule e folhas), foram necessárias doses de 277,4 e 143,3 g e.a. ha ${ }^{-1}$ de glyphosate, nos ensaios 3 e 4, respectivamente. Esse comportamento pode ser explicado pela área foliar, que no momento da aplicação era 5,85 vezes maior no ensaio 4 . Isso causou maior retenção foliar do produto e, consequentemente, maior absorção do herbicida pelas plantas. A absorção e translocação do glyphosate são influenciadas por diversos fatores, incluindo as características da planta, as condições ambientais, a concentração do herbicida, o surfatante utilizado e o método de aplicação.
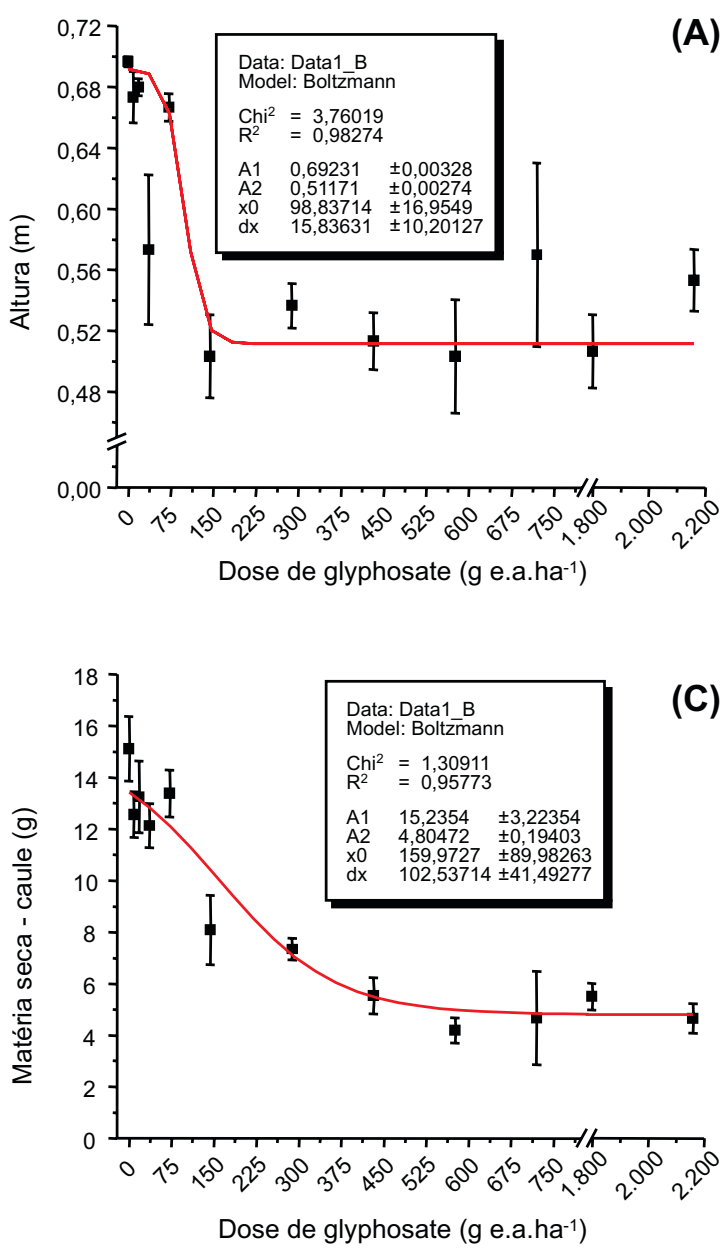

A absorção do glyphosate é um processo que envolve rápida penetração inicial através da cutícula, seguida por uma absorção lenta. A difusão é considerada o principal processo de transporte do glyphosate pela cutícula; portanto, o gradiente de concentração entre a região de deposição e o interior da planta influencia a absorção (Erickson \& Duke, 1981). A cutícula é primariamente apolar, mas existem diferenças com relação ao grau de hidrofobicidade devido à composição química das ceras. As ceras ricas em compostos triterpenoides, como o ácido ursólico, são altamente hidrorrepelentes, ao passo que as ricas em ésteres são mais hidroafins (Castro et al., 2005). Essas diferenças podem refletir na absorção do glyphosate, resultando em menor eficácia do produto quando a cutícula é mais hidrofóbica (Chachalis et al., 2001). Outros
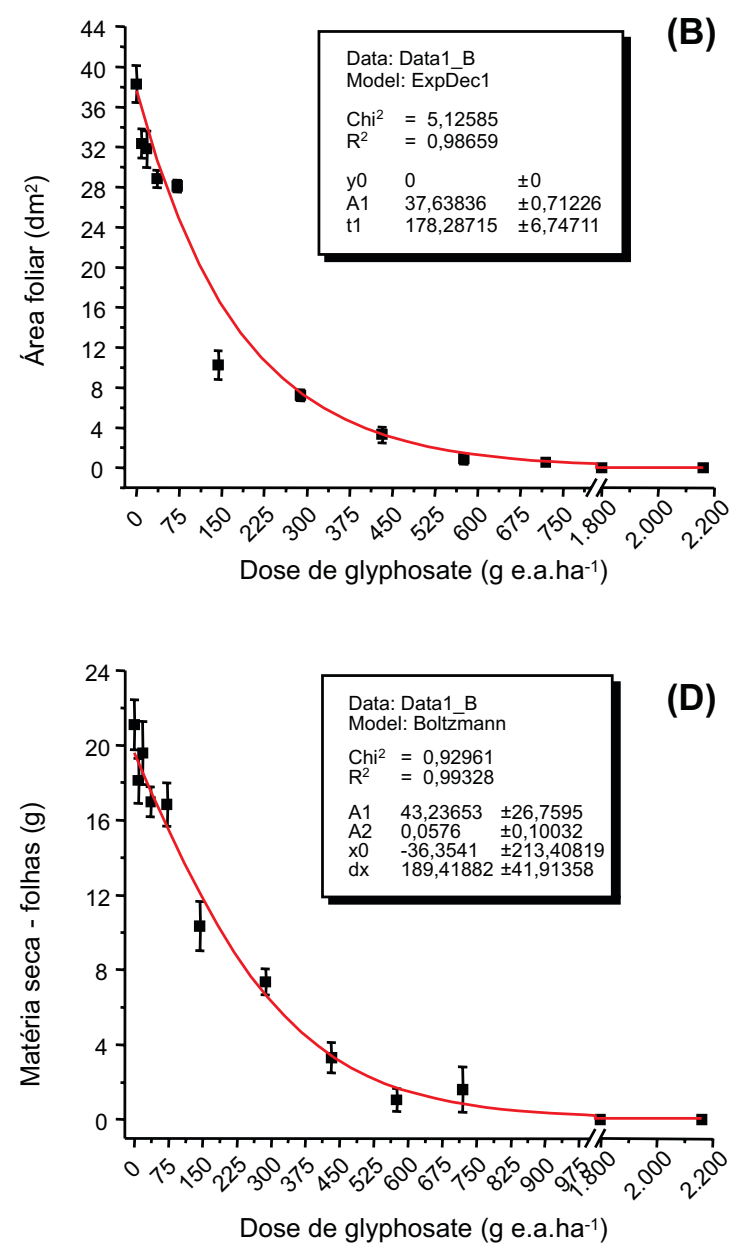

Figura 4 - Altura (A), área foliar (B) e matéria seca de caule (C) e folhas (D) de eucalipto submetido a aplicações de glyphosate (ensaio 4). 
fatores, como umidade superficial, idade da folha, estágio de crescimento, entre outros, vão influenciar diretamente a absorção e metabolização.

Segundo Schönherr (2002), a presença de água é fundamental para uma boa penetração de glyphosate nas folhas, sendo evidente que grande parte do herbicida que penetra em seus tecidos passa por poros hidratados da cutícula.

A densidade estomática também pode influenciar na absorção do glyphosate. Ela é variável de acordo com a idade da planta e diretamente influenciada pelas condições ambientais (Cao, 2000; Justo et al., 2005, citados por Tuffi Santos et al., 2006). Contudo, a correlação entre a porcentagem de intoxicação causada pelo glyphosate e as características indice estomático, densidade estomática e densidade de cavidades, nas duas faces epidérmicas das folhas de eucalipto, foi baixa e não significativa (Tuffi Santos et al., 2006). Isso pode ter ocorrido pelo fato de os estômatos serem estruturas muito mais eficientes para trocas gasosas.

As doses criticas de glyphosate encontradas neste trabalho variaram de $4,4 \cdot 10^{-3}$ a $3,7 \cdot 10^{-3}$ g e.a.por planta nas aplicações realizadas no caule e de 143,3 e 277,4 g e.a. por planta nas aplicações feitas em folhas. Isso demonstra que, mesmo em condições semicontroladas, existem variações quanto ao comportamento do produto em plantas jovens. Em razão disso, os efeitos negativos do glyphosate também estão sendo avaliados em campo. A idade das plantas no momento da(s) intoxicação(ões) e o tempo entre a intoxicação e a colheita podem atenuar os sintomas iniciais e serão decisivos na avaliação dos danos reais proporcionados por intoxicações com herbicidas.

\section{AGRADECIMENTOS}

A Marco Antonio Farias, Francisco Rigler Neto (in memoriam) e José Valcir Fidelis Martins, pelo apoio durante a condução dos ensaios. À empresa Fibria (Votorantim Celulose e Papel) e seus funcionários, pelo apoio, pelas sugestões e pelo financiamento da pesquisa.

\section{LITERATURA CITADA}

ASSOCIAÇÃO BRASILEIRA DE PRODUTOS DE FLORESTAS PLANTADAS - ABRAF. Anuário estatístico: Ano-base 2008/ABRAF - Brasília: 2009. 120 p.

AMARANTE JUNIOR, O. P. et al. Glifosato: propriedades, toxicidade, usos e legislação. Química Nova, v. 25, n. 4, p. 589-593, 2002.

BODE, L. E. Downwind drift deposits by ground applications. In: PESTICIDE DRIFT MANAGEMENT SYPOSIUM, 1984, Brookings. Proceedings... Brookings: South Dakota University, 1984. p. 49-52.

BREDONLAN, R. A. et al. Efeitos da nutrição mineral na competição inter e intraespecífica de Eucalyptus grandis e Brachiaria decumbens: 1- crescimento. Sci. For., n. 58, p. 49-57, 2000.

CASELEY, J. C.; COUPLAND, D. Environmental and plant factors affecting glyphosate uptake, movement, and activity. In: GROSSBARD, E.; ATKINSON, D. (Eds.) The herbicide glyphosate. London: Butterworths, 1985. p. 92-123.

CASTRO, P. R. C. et al. Manual de fisiologia vegetal: teoria e prática. São Paulo: Agronômica Ceres, 2005. 651 p.

CHACHALIS, D. et al. Characterization of leaf surface, wax composition, and control of redvine and trumpetcreeper with glyphosate. Weed Sci., v. 49, n. 2, p. 156-163, 2001.

CUNHA, J. P. A. R. Simulação da deriva de agrotóxicos em diferentes condições de pulverização. Ci. Agrotec., v. 32, n. 5, p. 1616-1621, 2008

ERICKSON, C. G.; DUKE, W. B. The effect of glyphosate and surfactant concentrations on penetration and translocation in quack grass. Proc. Northeast. Weed Sci. Soc., v. 35, p. 52, 1981.

MAGALHÃES, P. C. et al. Efeito de doses reduzidas de glyphosate e paraquat simulando deriva na cultura do sorgo. Planta Daninha, v. 19, n. 2, p. 255-262, 2001.

MACHADO, A. F. L. Tolerância de genótipos de eucalipto ao glyphosate. 2009. 65 f. Tese (Doutorado em Fitotecnia) Universidade Federal de Viçosa, Viçosa, MG, 2009.

MILLER, D. K. et al. Response of nonglyphosate resistant cotton to reduced rates of glyphosate. Weed Sci., v. 52, n. 1, p. 178-182, 2004.

SCHÖNHERR, J. A mechanistic analysis of penetration of glyphosate salts across astomatous cuticular membranes. Pest Manag. Sci., v. 58, n. 4, p. 343-351, 2002.

TAIZ, L.; ZEIGER, E. Fisiologia vegetal. Porto Alegre: ARTMED, 2004. 750 p.

Planta Daninha, Viçosa-MG, v. 29, n. 4, p. 913-922, 2011 
TAKAHASHI. E. N. et al. Conseqüências da deriva de clomazone e sulfentrazone em clones de E. grandis $\mathrm{x}$ E. urophylla. R. Árvore, v. 33, n. 4, p. 675-683, 2009.

TAROUCO, C. P. et al. Períodos de interferência de plantas daninhas na fase inicial de crescimento do eucalipto. Pesq. Agropec. Bras., v. 44, n. 9, p. 1131-1137, 2009.

TOLEDO, R. E. B. et al. Faixas de controle de plantas daninhas e seus reflexos no crescimento de plantas de eucalipto. Sci. Flor., n. 64, p. 78-92, 2003
TUFFI SANTOS, L. D. et al. Crescimento e morfoanatomia foliar de eucalipto sob efeito de deriva do glyphosate. Planta Daninha, v. 23, n. 1, p. 133-142, 2005

TUFFI SANTOS, L. D. et al. Intoxicação de espécies de eucalipto submetidas a deriva de glyphosate.

Planta Daninha, v. 24, n. 2, p. 359-364, 2006.

YAMASHITA, O. M.; GUIMARÃES, S. C. Resposta de cultivares de algodoeiro a subdoses de glyphosate

Planta Daninha, v. 23, n. 4, p. 627-633, 2005. 